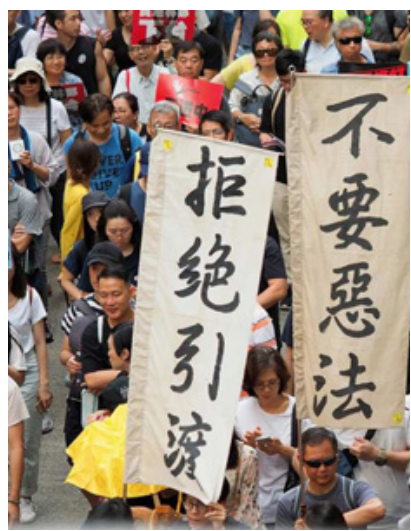

"No ferocious law, refuse China extradition", protesters rally in Hong Kong. PC: @etanliam2019 (Flickr.com).
As in the last major moment of protestthe Occupy Central movement of 2014Beijing has again accused Hong Kong's protesters of acting under the influence, if not direction, of foreign powers.

\section{A Global Path through the Hong Kong Dillemma Towards a New Internationalism}

Jake WERNER

ecent weeks have seen the reemergence of an extraordinary protest movement in Hong Kong. Perhaps one million of the city's seven million people turned out on 9 June to demand the withdrawal of an extradition bill put forward by Hong Kong Chief Executive Carrie Lam that would have left people in Hong Kong vulnerable to politically motivated extradition to mainland China. Perhaps two million came out on 16 June, even after Lam suspended consideration of the bill in response to police clashes with protesters on 12 June.

The movement is ongoing, having extended its demands to accountability for police violence, the resignation of Lam, and universal suffrage for the city's elections. Its future direction, however, is unclear. Powerful secessionist tendencies are at work and many protesters frame their conflict as one between their own local identity and the supposedly incompatible culture of mainland China. Yet internationalism and solidarity with popular struggles on the mainland are also present.

There are no indications, however, that the Chinese leadership will soften its insistence on ultimately integrating Hong Kong into the authoritarian system of the mainland. As in the last major moment of protest-the Occupy Central movement of 2014-Beijing has again accused Hong Kong's protesters of acting under the influence, if not direction, of foreign powers (Zhang 2019). In the years since 2014, it has encouraged a range of repressive measures targeting those who took part in Occupy, from blocking elected members of the Legislative Council from taking their seats to imprisoning protest organisers. And it has stood firm in its determination to prevent direct elections for either the chief executive or the full Legislative Council.

These events have left the impression that Hong Kong and mainland China are polar opposites: the liberal democratic values and cosmopolitan openness of a great global city facing off against an increasingly nationalist and authoritarian mainland regime. That, in turn, has inspired a sense of hopelessness that democracy can ever triumph in Hong Kong. As The Wall Street Journal put it, the protests represent 'the last flickering flame of resistance to a rising oppressor' (Baker 2019). 
Bringing to light new possibilities is of vital importance not just for Hong Kong and China, but for the entire world.
Yet a closer look at the conflict reveals a less fixed set of identities and a more complex political trajectory. On the one hand, recognising these dynamics undermines the simple binary of freedom against tyranny, but on the other hand it opens the possibility of overcoming today's irreconcilable oppositions and achieving a freer society on both sides of the border. The key to such an analysis is to place the seemingly local question of Hong Kong's governance within the global context that has produced the conflict. The task is urgent and the stakes are enormous. Bringing to light new possibilities is of vital importance not just for Hong Kong and China, but for the entire world.

Antipathy in Hong Kong against mainland China is driven not only by the looming threat of authoritarianism, but also by popular resentment at the increasing presence of mainland Chinese in the city. Attacked for everything from buying up the supply of infant formula to engaging in uncivilised behaviour in public spaces, mainland Chinese tourists, students, and workers have found themselves harassed on the street and denounced in the media with quasi-racist slurs. In the words of the organiser of a full-page newspaper ad against mainlanders: 'Why are mainland mothers flooding in to take up resources in public hospitals, getting our benefits and social welfare? Why do mainlanders ... refuse to follow our rules and order?' (SCMP 2012; Tsang 2015). Such attacks echo anti-migrant politics worldwide.

The mainland is symbolically linked not only to the everyday presence of these maligned sojourners, but also to a more abstract sense of powerlessness because Hong Kong's elite is taken to be an instrument of Beijing. A few families have accumulated enormous wealth by dominating the key economic sectors of property, ports, communications, and power generation. In 2017, the top five tycoons took 23.6 billion HKD ( 3 billion USD) in dividends from their primary listed companies alone, income that in Hong Kong's laissez-faire system goes entirely untaxed (Bland 2018). The power of the economic elite is institutionalised in Hong Kong politics in an unusually open way because Beijing designed the mixed electoral and appointed legislature to ensure corporate control (Hung 2010). Thus, the question of democracy is inseparable from the question of how the people of Hong Kong can exert influence against the Beijing-business axis. 
The urgency of this question lies in the deteriorating possibilities for a decent life in Hong Kong. The percentage of university graduates in the city has more than tripled over the last 25 years, yet wages have been sluggish or flat for the bottom two-thirds of the population (Cartledge 2017, 25-27). Median starting pay for new graduates in 2017 was 10 percent lower than it was in 1992 ( $\mathrm{Ng}$ and Choi 2019).

As in the other financial centres around the world, incomes and job opportunities have sharply polarised in the era of free market globalisation. As manufacturing has shifted across the border to Guangdong province, the growth of well-paid jobs in finance and the other professions has been dwarfed by the increase of poorly paid service jobs performing menial tasks for the professionals (Wong 2018; Ng and Choi 2019). Workers in Hong Kong endure the longest working hours of any global city-a problem afflicting the privileged and poor alike-which the government has long discussed but never addressed due to business opposition (Ng and Leung 2018; Liu 2018). At the same time, the people of Hong Kong face the world's most expensive housing market (Ting 2019).

Mainland China is closely associated with all of these issues. The influence of mainland property speculators has driven the cost of housing up ever further (Cheng 2017). Hong Kong university students feel growing pressure from their mainland rivals (Bland 2017, 39-40). The major labour union federation is dominated by Beijing, and helped to repeal the right to collective bargaining that Hong Kong workers briefly enjoyed in 1997. Today it denounces the democracy protests (Cheng 2015; China Daily 2019). Finally, Beijing is now implementing its plan for a Greater Bay Area, the aim of which is to deepen the presence of the mainland by tightly integrating Hong Kong into the transportation, communication, and economic systems of Guangdong.

Thus, the discontent expressed in the protests draws together different forms of popular suffering and fear whose immediate experience is linked in various ways to the presence of mainland China in Hong Kong (Peter 2019). The breadth of these sentiments is reflected not only in the size of the protests, but also in the sharp decline after 2008 in various measures of identification with the mainland (Public Opinion Programme 2019; Centre for Communication and Public Opinion Survey 2016).

As shown in the graph below, the percentage of Hong Kong citizens expressing pride in being a citizen of China is closely correlated with the degree of satisfaction in livelihood conditions. While thoughts about democracy and individual identity should not be reduced to narrowly economic facets of 
life, neither should they be divorced. Each is caught up in the other, and in recent years all have been pointing in the same direction. With the erosion of individual opportunity and the sharpening of exclusionary economic and political dynamics in Hong Kong society, a politics aimed at pushing out the presence of mainland China increasingly seems like the only one adequate to the challenge.

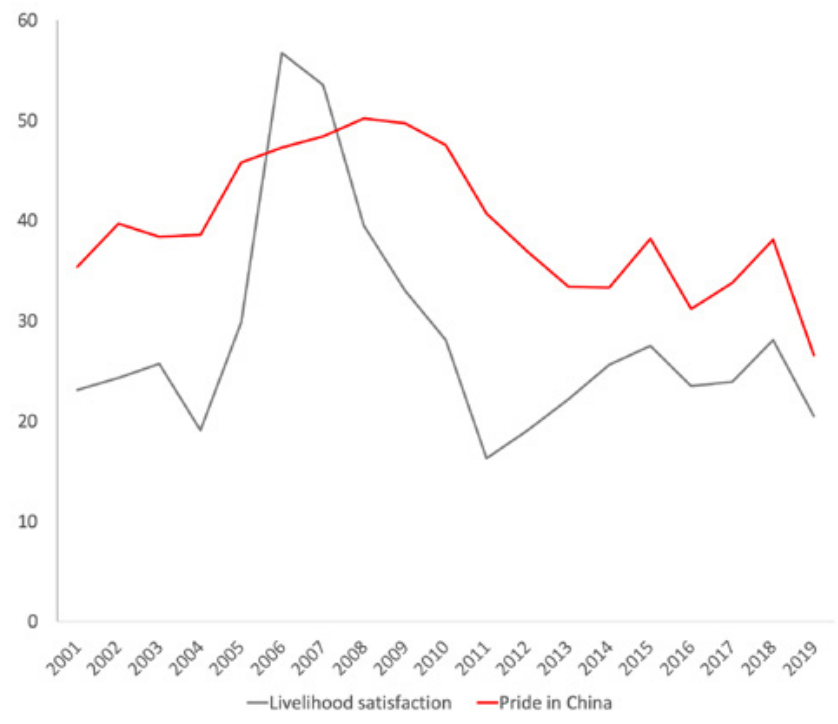

Data: Public Opinion Programme

Yet the sense that hostile outsiders and heartless elites are ruining the future of the common people is hardly unique to Hong Kong. The populist desire to solidify a common in-group identity in order to mobilise the people against these forces is likewise widespread. The mass emergence of these themes across many countries over the last decade indicates that their ultimate sources must be traced deeper than mainland China. What rising populisms both left and right around the world have in common is the shared experience of extreme inequality and intense competitive pressures, which has generated an acute sense of scarcity around jobs and resources alongside a growing sense of having lost control over decisions about the future to shadowy alien powers.

If the nature of the discontent is widely shared, Hong Kong is nonetheless unusual in the way a single concept-China-seems capable of explaining resentments felt against both the elite above and the uncivilised outsider below. That, in turn, nurtures a kind of quasi-nationalist localism as the form of politics that seems to address the whole range of grievances. The problem with such a politics is not only that it focuses on the immediate 
sources of oppression rather than the deeper dynamics. The more pressing danger is that the advance of localist politics in Hong Kong may radicalise Chinese nationalism.

Just as the people of Hong Kong have faced an increasingly fraught socioeconomic landscape over the last two decades, so too have the people of mainland China. The market reforms of the 1980s and 1990s generated not just rapid economic growth but also high levels of inequality, corruption, and popular unrest. Around the turn of the century, the Communist Party leadership sought to alleviate these tensions by strengthening social protections and opening up space for NGOs and activists to press the claims of disadvantaged social groups. A decade of slow but genuine liberalisation across a wide range of social realms followed, in which a host of Hong Kong-based solidarity organisations played an important role (Hung and Ip 2012).

But the financial crisis of 2008 , rising international tensions, and growing popular nationalism-three tightly entangled phenomena-led to a sharp reorientation. The Chinese leadership recentralised power, clamped down on dissent, and became increasingly suspicious of 'foreign' influences-trends that have intensified under Xi Jinping but that predate his ascent to power. Within this general repudiation of liberalisation, the Standing Committee of the National People's Congress issued its notorious 2014 decision limiting candidates for Hong Kong chief executive to those acceptable to Beijing, setting off the Occupy Central protests (SCMP 2014).

The $\mathrm{Xi}$ administration reacted strongly against those protests for two key reasons. First, Chinese leaders feared the unrest not because it was alien but because Hong Kong's social landscape mirrored so closely the situation in the rest of China. The same discontent with extreme inequality, instability, overwork, competition, corruption, and elite unaccountability haunts every city in China. On the mainland, it has proven difficult to mobilise this anger, both because of the state's tight control over dissent and because there is no single target against which to direct the full range of resentments. China's leaders are nonetheless convinced that political liberalisation would unleash these pressures. Giving in to the Hong Kong democrats thus endangers the delicate authoritarian settlement that has thus far sustained market-driven growth in China.

Chinese leaders' feeling of internal insecurity has now been seriously aggravated by a growing sense of external threat. The discrediting of neoliberal economic doctrine in 2008 and the need to accelerate development to deal with a drop in export demand led Chinese leaders to assert increasing state control in 
The Hong Kong

protests, then,

represent a practical

challenge to Beijing's

goal of maintaining

control, but they also

pose a symbolic and

ideological challenge to

the fate of the nation. the economy, as embodied in the 'Made in China 2025' industrial policy. This posed a growing challenge to a US economy facing its own serious challenges after 2008, inspiring the Trump administration's campaign to prevent China's development of high-value production (Werner 2018). Whereas Hong Kong's frustration with the status quo is directed against mainland China, in mainland China the immediate appearance of threat and restriction is the United States, 'Western civilisation', and liberal values.

The Hong Kong protests, then, represent a practical challenge to Beijing's goal of maintaining control, but they also pose a symbolic and ideological challenge to the fate of the nation. Chinese leaders believe that for the nation to survive and prosper, the population of the entire country-today fragmented and often unreliable-must be unified and regimented to compete successfully within an increasingly zero-sum global economy. From this perspective, the Hong Kong protesters not only reject that project, they also betray the nation in service to foreign values and foreign schemes.

The most common framings of the Hong Kong-China conflict have posed it in moralising terms (freedom vs authoritarianism; treason vs loyalty to the nation) or as a clash of cultures (colonial or cosmopolitan vs Chinese). These binaries represent the conflict as one of fixed positions whose resolution can only be the defeat of one side or the other. They also tend to encourage such an eventuality by increasingly hardening identities within their oppositional terms.

If, instead, we step back from the immediate conflict and analyse the structure that has given rise to such incompatible positions, then we open the possibility that a new political path might resolve the antagonism by creating different possibilities that overcome these binaries.

The structural development in question is not specific to Hong Kong or to China. It is, rather, the slow disintegration of the dominant global system of political economy-free market globalisation-since 2008. The collapse of the global economy was narrowly averted in that year, but the forms of economic growth and social reproduction that had previously integrated a growing number of people around the world into the system did not recover their former vitality. Instead, more and more people either face mounting difficulty finding a place in society, or they experience their participation in it as a source of suffering rather than possibility. 
Hence the rejection of the status quo is a global phenomenon. Yet the forms of appearance assumed by the status quo-and with it, who is blamed for the suffering-vary widely depending on the position one occupies within the system. People in both Hong Kong and mainland China have turned against the social forms that sustained neoliberal growth over the last four decades, above all the concentration of economic and political power, the corruption that grows from it, and the cosmopolitan process of integration that expands its ambit. Yet, the concrete bearers of these forces are differentiated in a way that turns distinct parts of a common rebellion against each other. Ideologies of exclusion and separation are the outcome.

Nationalists and localists of all varieties-those in the United States and Europe as much as those in Asia-are perfectly right to recognise that their suffering is deepened by further integration into the existing system of growth. But they are quite wrong to think that seceding from that system offers any sort of solution. Instead, the attempt will only deepen the dysfunction through a cycle of escalating conflict as each nationalism feeds on the others and strangles the possibility of progressive politics in all countries.

However, apprehensions of the status quo are determined not only by one's structural position but also by the political experiences to which one is exposed. This means a politics that configures the sharp social tensions of a disintegrating global system in a different way could avert the current movement toward world conflict.

The politics that could break the cycle of rising antagonisms is not the severing of connections across borders but their deepening. The people of Hong Kong have a great deal in common with those on the mainland, as both groups do with the people of Vietnam, India, Iran, Sudan, South Africa, Brazil, and the United States. All face an elite that is unresponsive to popular pressures due to an extreme concentration of wealth and power. All suffer the instabilities of eroding social protections, speculative bubbles, intensifying nationalist conflict, and a deteriorating natural environment. Joining together to remake the global system around an egalitarian set of principles-universal labour rights, dramatically increased investment in capital-starved regions, international cooperation in the transition to green production-would confront the deep sources of suffering and reduce the insecurities that have promoted intolerance and authoritarianism around the world.

In the Hong Kong context, the immediate work of such a politics would be repositioning democracy from a localist demand to one of solidarity with popular struggles on the mainland. This would confound Beijing's attempt to tar the democracy agenda as an anti-China scheme, demonstrating 
instead that the Hong Kong movement stands with the people of China. By breaking out of the US-China and liberal-national binaries, it would help to mitigate the insecurities that are fuelling Chinese nationalism.

The short-term goal-possible if (but only if) the next US president sharply reorients China policy-would be a return to the political environment of the 2000s on the mainland, lifting state repression and allowing the return of grassroots politics. Opening space for those struggles would not only move mainland China in a progressive direction, it would help shift political attention within Hong Kong to the deeper social forces within the city imposing popular disfranchisement. The longterm goal towards which all this would build is a new structure of global growth. A progressive form of globalisation would sustain further integration, but in sharp contrast to neoliberal globalisation, it would accomplish integration by reducing inequalities and extending productive investment to the vast numbers today excluded from growth.

Such an internationalism is just as essential a part of Hong Kong identity as the more exclusionary currents that have been gaining strength. From the general strike of 1925, in which half of all workers in Hong Kong stood together with the labour and anti-imperialist movement on the mainland, to today's labour organisations like Students and Scholars Against Corporate Misbehaviour (SACOM), Worker Empowerment, Globalisation Monitor, or China Labour Bulletin, to name but a few of the groups supporting workers on the mainland, Hong Kong's position both inside and outside of China has made it an essential site for connecting the country to transnational movements.

In such a project, the demand to preserve Hong Kong's autonomy and expand its freedoms is not superfluous but essential. The fight for a progressive globalisation as the alternative to both free market globalisation and nationalist disintegration cannot succeed without securing China's cooperation. Hong Kong's defence of the diminishing space to articulate a different vision for the future of China and to practice the politics that might bring it about is thus indispensable. The future of global society may turn on what happens in Hong Kong over the coming weeks and months-not only whether the struggle for democracy grows stronger, but how the movement defines its vision for the future as well. 